\title{
Comment on "Cytokines and Oxidative Stress Status following a Handball Game in Elite Male Players"
}

\author{
Matthias Weippert, Regina Stoll, Annika Rieger, and Steffi Kreuzfeld \\ University of Rostock, Institute of Preventive Medicine, St.-Georg-Straße 108, 18055 Rostock, Germany \\ Correspondence should be addressed to Matthias Weippert, matthias.weippert@uni-rostock.de \\ Received 8 June 2012; Accepted 18 June 2012 \\ Copyright ( 2012 Matthias Weippert et al. This is an open access article distributed under the Creative Commons Attribution \\ License, which permits unrestricted use, distribution, and reproduction in any medium, provided the original work is properly \\ cited.
}

In a well-conducted study, Marin et al. [1] reported significant alterations of oxidative stress biomarkers, antioxidant capacity, and indices of muscular damage in elite handball players after a friendly match. The authors were surprised by the marked increase of muscular damage indirectly assessed by serum creatine kinase $(\mathrm{CK})$ in experienced players, which increased from about $80 \mathrm{U} / \mathrm{L}$ at baseline to $150 \mathrm{U} / \mathrm{L} 24$ hours after game. However, average CK values reported here are quite low in comparison to reference values of athletic populations [2] and do not exceed reference values used in clinical practice $[3,4]$. Although containing lots of eccentric exercises like abrupt stopping or landing after jumping and the risk of muscle injury due to direct contact with other players, the average 24-hour postmatch value reported by Marin and colleagues reached only $20 \%$ of the upper reference level of swimmers. Swimmers generally exhibit low CK levels because of the non-weight-bearing, noncontact, and concentric nature of their sport $[2,5,6]$. We investigated twenty-one elite handball players to obtain representative values during a regular play-off season and found 12hour postmatch CK values of $347 \mathrm{U} / \mathrm{L}$ (SEM: $43 \mathrm{U} / \mathrm{L}$ ) and values of $255 \mathrm{U} / \mathrm{L}$ (SEM: $38 \mathrm{U} / \mathrm{L}$ ) during a normal training week (60 hours after match). The relatively low values reported by Marin et al. are due to the study design, which included the abstinence from handball training and games before a friendly match for 2 and 4 days, respectively. Furthermore, serum CK is not always an (indirect) marker of muscular damage, but rather reflects increased rates of muscle turnover, stimulated by muscle use [6-8]. Thus, a 2fold and even higher increase in response to exercise is not surprising $[6,9,10]$.

\section{References}

[1] D. P. Marin, C. dos Santos Rde, A. P. Bolin, B. A. Guerra, E. Hatanaka, and R. Otton, "Cytokines and oxidative stress status following a handball game in elite male players," Oxidative Medicine and Cellular Longevity, vol. 2011, Article ID 804873, 10 pages, 2011.

[2] V. Mougios, "Reference intervals for serum creatine kinase in athletes," British Journal of Sports Medicine, vol. 41, no. 10, pp. 674-678, 2007.

[3] W. H. Bagley, H. Yang, and K. H. Shah, "Rhabdomyolysis," Internal and Emergency Medicine, vol. 2, no. 3, pp. 210-218, 2007.

[4] G. Schumann, R. Bonora, F. Ceriotti et al., "IFCC primary reference procedures for the measurement of catalytic activity concentrations of enzymes at $37^{\circ} \mathrm{C}$," Clinical Chemistry and Laboratory Medicine, vol. 40, no. 6, pp. 635-642, 2002.

[5] T. D. Noakes, "Effect of exercise on serum enzyme activities in humans," Sports Medicine, vol. 4, no. 4, pp. 245-267, 1987.

[6] M. Totsuka, S. Nakaji, K. Suzuki, K. Sugawara, and K. Sato, "Break point of serum creatine kinase release after endurance exercise," Journal of Applied Physiology, vol. 93, no. 4, pp. 12801286, 2002.

[7] M. Hagberg, G. Michaelson, and A. Ortelius, "Serum creatine kinase as an indicator of local muscular strain in experimental and occupational work," International Archives of Occupational and Environmental Health, vol. 50, no. 4, pp. 377-386, 1982.

[8] S. A. Malcolm, A. Anstee, and H. Halloran, "Time course changes in plasma creatine kinase over four days of repetitive manual work," Ergonomics, vol. 38, no. 5, pp. 1019-1024, 1995.

[9] P. Brancaccio, G. Lippi, and N. Maffulli, "Biochemical markers of muscular damage," Clinical Chemistry and Laboratory Medicine, vol. 48, no. 6, pp. 757-767, 2010. 
[10] D. V. De MacEdo, L. A. S. Nunes, and R. Brenzikofer, "Reference change values of blood analytes from physically active subjects," European Journal of Applied Physiology, vol. 110, no. 1, pp. 191-198, 2010. 


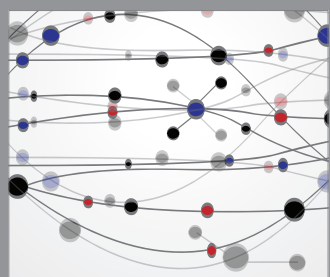

The Scientific World Journal
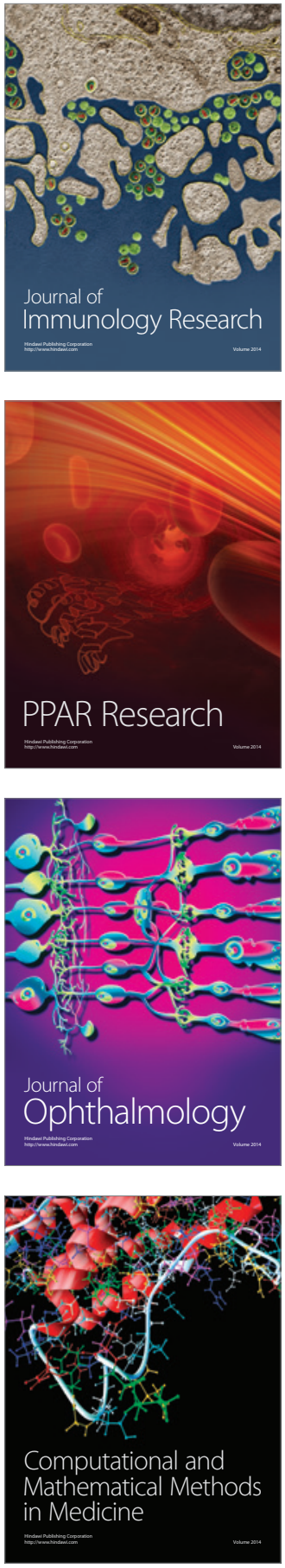

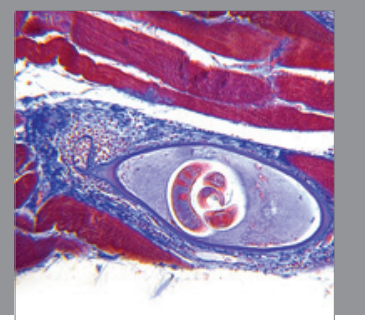

Gastroenterology

Research and Practice
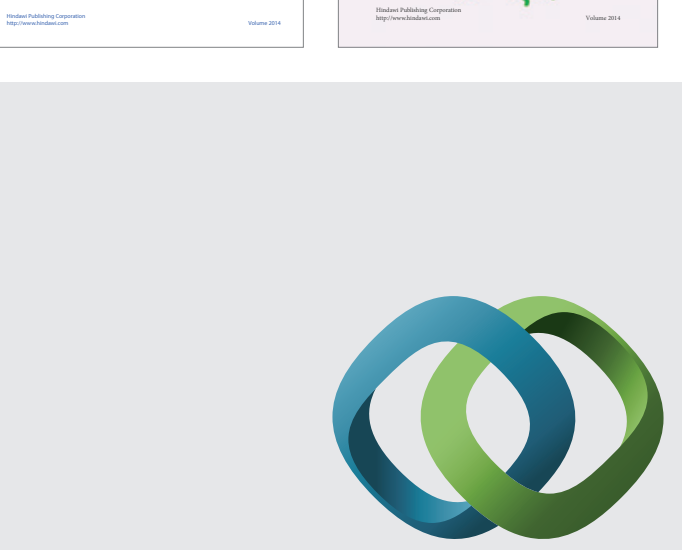

\section{Hindawi}

Submit your manuscripts at

http://www.hindawi.com
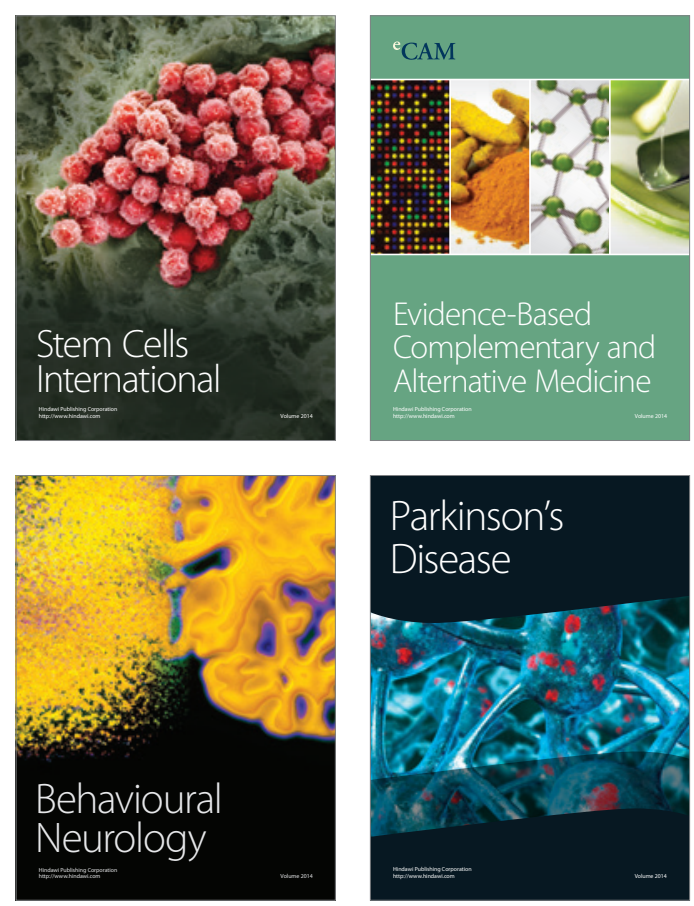

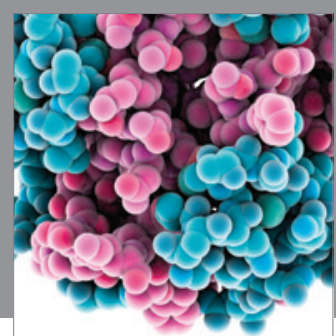

Journal of
Diabetes Research

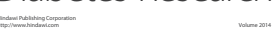

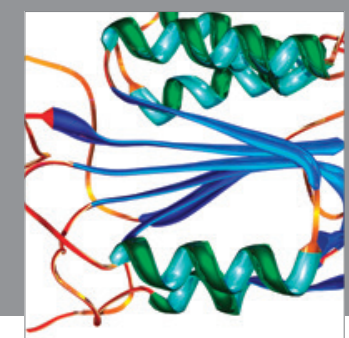

Disease Markers
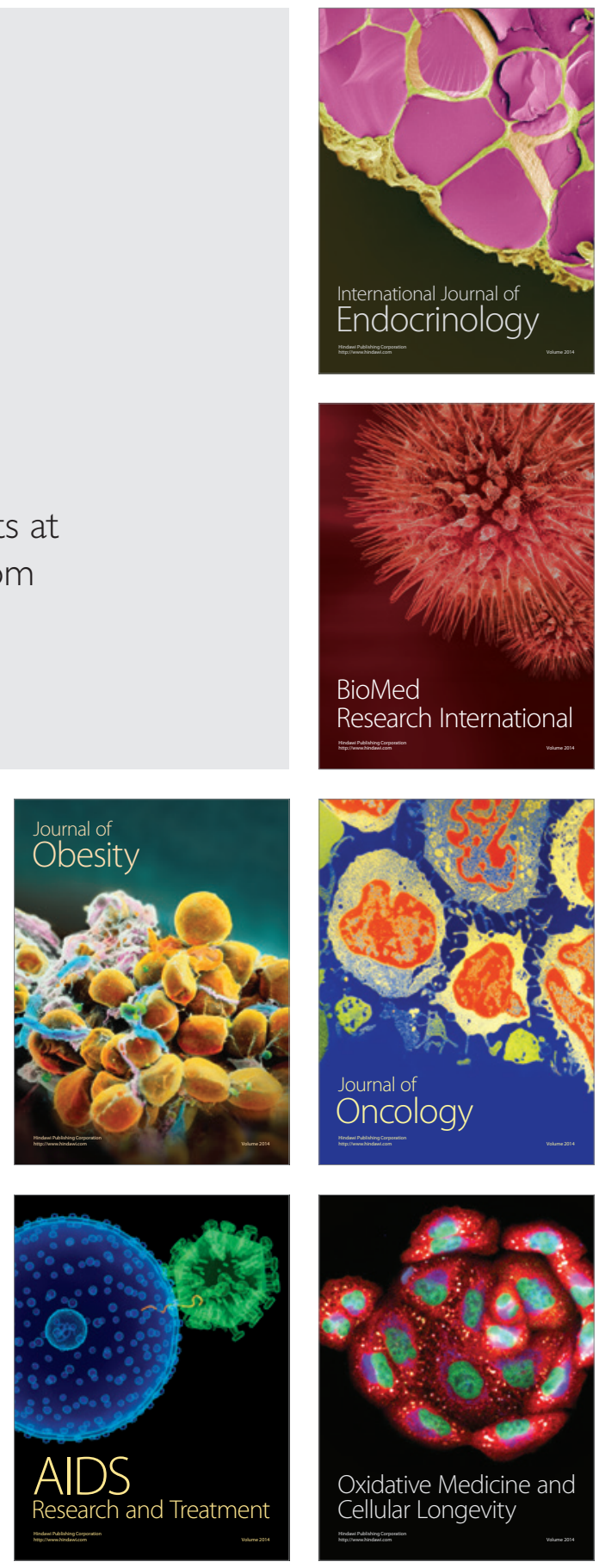